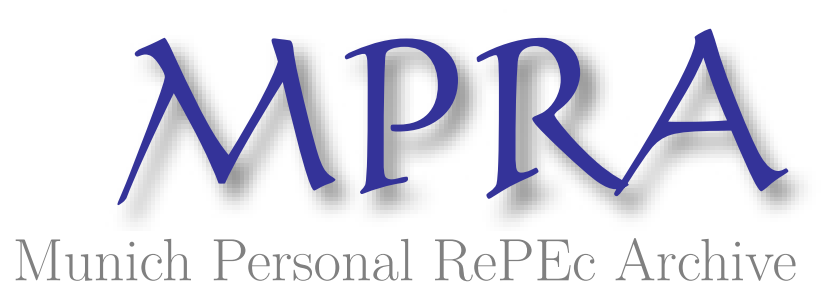

\title{
The internal limits to firms' nonmarket activities
}

Bonardi, Jean-Philippe

University of Lausanne

2008

Online at https://mpra.ub.uni-muenchen.de/14500/

MPRA Paper No. 14500, posted 07 Apr 2009 04:49 UTC 


\title{
THE INTERNAL LIMITS TO FIRMS' NONMARKET ACTIVITIES
}

\author{
Jean-Philippe Bonardi \\ University of Lausanne \\ Faculty of Business and Economics \\ Dorigny - Internef - Lausanne - 1015 \\ Tel: (00 41) 216923440 \\ E-mail: jbonardi@unil.ch
}

June 2008

\begin{abstract}
It is well documented that firms develop nonmarket strategies in an effort to shape public policy changes to their advantage. But are there no limits to this? This paper argues that there is, in fact, an important limitation, internal to the firm, that stems from the necessity for firms to integrate market and nonmarket activities. Because the two types of activities are not always complements but sometimes substitutes, firms end up forgoing part of their nonmarket activities to avoid restricting the development of their market strategies. This argument is tested in the context of the European telecommunications industry. Results suggest that there is reasonable ground for optimism regarding the potentially negative influence that firms' nonmarket activities might play in a democracy.
\end{abstract}




\section{Introduction}

$\mathrm{n}$ democracies, societal improvement often comes as a result of public policy changes.
Hence, changes affecting many industries are presented as opportunities by which to
enhance social welfare. However, these policy changes might not be as beneficial as anticipated, since corporate interests often influence political processes on order to try to shape new policies to their advantage (Reich, 1998). Regarding a social issue like climate change, for instance, more than 20 industry associations in a country like Canada have registered on their behalf or hired lobbyists to represent them. The same can be said about large companies such as Shell, Encana, Ford, Alcan, Dofasco, TransAlta or Pepsico. ${ }^{i}$ When such strong corporate influence is exerted on a political issue, what guarantee is there that a broad portion of people in the Canadian society will benefit from the policy decisions being made? This potential problem is, in fact, well documented in the political science and economics literature, especially for regulated industries (Baumol and Ordover, 1985; Tullock, 1967; Stigler, 1971), but also in deregulated ones (Derthick and Quirck, 1985; McCormick et al., 1984; Teske, 1991). This literature supports the idea that firms $d o$ have a significant influence on policy changes, which means there is a possible trap that might reduce the potential for policy changes to enhance social welfare (Troesken, 2007; Tullock, 1975). A broad objective of this paper is to explore how management research can contribute to shedding some light on this issue.

From the perspective of the management literature, this proposition is, at first glance, reinforced by the research on firms' nonmarket strategies - defined broadly as the set of activities and tactics firms use to influence public policies (Baron, 1995) and corporate political activities (Hillman and Hitt, 1999). Whereas the empirical literature on campaign financing has been largely inconclusive on the ability of firms to buy votes and policies (Ansolabehere, de 
Figueiredo and Snyder, 2003; Zardkoohi, 1985), the more recent literature on firms-government relationships delivers a stronger message. Recent work on lobbying (de Figueiredo and Silverman, 2006) politically connected firms (Faccio, 2006, 2007; Faccio, Masulis and McConnell, 2006; Fisman, 2001; Hillman, 2005; Hillman, Zardkoohi and Bierman, 1999) or firms' nonmarket capabilities (Bonardi, Holburn and Vanden Bergh, 2006; Dean and Brown, 1995; Henisz, 2003; Keim and Baysinger, 1988; Oliver and Holzinger, 2007) - suggests that organizations with connections, reputation or skills to deal with policy-makers tend to be effective at pushing policies towards their own preferred points. Hence, this scenario represents a potential threat for public policy changes.

This issue has broad implications, not only for the nature of public policies or for policymaking processes themselves, but also for society. Many stakeholders are indeed affected: consumers, through the prices they pay or the quality of the products/services they get, depending on the nature of industry structures affected by policy changes; employees, who sometimes share the rent created; and many other individuals who are not directly involved in the industry but who might experience some spillovers related to the new policies that have been adopted. These individuals might, in fact, have to organize for collective action against the rise of corporate influence over public policy-making.

This paper will argue that there are, however, limitations to firms' nonmarket activities. We will show that these limitations are both external (related to the nature of their external environment) and also internal. Exploring the nature of these internal limitations is the main contribution of this paper. We will argue that these internal limits are related to the difficulty for firms, at a certain point of their development, to integrate market and nonmarket activities. Because successful nonmarket activities require the commitment of certain market inputs, these 
nonmarket activities often become substitutes for market activities. In that case, firms' managers face trade-offs and are likely to favor market strategies over nonmarket ones. For instance, in an analysis of the integration by former telecom monopolies of defensive nonmarket strategies (to protect their home market) and of aggressive international strategies (to penetrate other markets), Bonardi (2004) finds that the market and the nonmarket aspects do not always work as perfect complements, thereby making some types of integration unsustainable.

The next section develops a theory of limitations to firms' nonmarket activities. This theory is then tested within the context of policy changes in the European telecommunications industry (1983-2000). The final section discusses the results and offers some conclusions.

\section{Theory}

Several studies have shown that nonmarket activities have a substantial impact on firms' performance (Hillman et al., 1999). As argued by Baron (1995), nonmarket activities are particularly important as they allow firms to control their attainable opportunities. This is particularly true in regulated markets, in which many of these opportunities are controlled by government bodies. To enter a sector that is being deregulated, such as electricity or telecommunications, or to operate in sectors such as the pharmaceutical sector or biotechnology, firms need regulatory approvals. Not only do nonmarket activities provide a way to enter regulated markets, but they also shape policy changes in these markets. They can also provide a way for firms to obtain subsidies or secure competitive advantages through technologies adopted as public standards or environmental norms (Dean and Brown, 1995). Two conclusions can be drawn. First, firms can derive clear advantages from nonmarket activities, all the more so in industries where national regulations play a role. Second, there is a natural complementarity 
between market and nonmarket activities in these industries. Obtaining the right to operate and develop market strategies or gaining a competitive advantage in these industries often requires firms to build on their complementary market and nonmarket strategies (Baron, 1995; Bonardi, 2004; Shaffer et al., 2000).

The literature on nonmarket activities also points out why firms, especially large ones, often tend to be more effective in the political arena than are competing interest groups (of individuals, consumers, activists, etc.). Hillman and Hitt (1999) explain that players in political arenas compete by providing three incentives to policy-makers: financial incentives (such as campaign contributions), information (especially through lobbying activities) and votes (often provided through constituency-building). Hence, in many situations, firms have an advantage over interest groups in providing these three incentives. First, large firms have deep pockets and are certainly among the largest actors regarding political campaign financing. Second, large firms or groups of firms (for instance, industry associations) generally have private information about the products or technologies that are being considered by the regulators. And when they don't, they can command research and large studies that will generate important data (Bonardi et al., 2006). Competing interest groups often don't have this capacity. Third, by their very nature, firms are already 'organizations' of actors (managers, employees, suppliers, unions, etc.), which reduces the costs of collective actions when they try to build support from their constituents. Through this organizational advantage, firms are often quite effective at leveraging votes for politicians seeking re-election (Keim and Baysinger, 1988).

The conclusion here is that firms not only have a natural interest in integrating market and nonmarket activities within many industries, but they are also likely to be successful at developing effective nonmarket actions to support their market strategies. Does this mean there 
is no limit to firms' nonmarket activities? If they are so important and likely to be successful, one can imagine that nonmarket activities would grow within firms in an exponential way. As discussed earlier, this would raise important questions for the relationships between corporate interests and society within the context of a democracy. In what follows, we explore the potential limitations to firms' nonmarket activities.

\section{External limits to nonmarket activities}

As summarized in Figure 1, one can identify both external and internal limits to firms' nonmarket activities. External limits to firms' nonmarket activities, i.e., limits related to the nature of firms' external environment, have been explored in previous literature and can be divided into three categories. The first category is related to the rules of the democratic game in the different countries, rules that, by law, constrain the type and amount of nonmarket activities in which firms can engage. These rules vary by country, as formal and informal insitutional rules regulate nonmarket activities (Hillman and Keim, 1995). These rules are of less interest to researchers in management though, as they apply similarly to all firms and constitute a legal framework in which these nonmarket activities can actually thrive. Furthermore, changing the rules would likely generate a lot of nonmarket activities by individual firms, thereby defying the idea that the rules themselves are pure limitations to nonmarket activities.

The second external limit is related to the nature of the nonmarket competition faced by the firm. In spite of what has been suggested earlier, firms sometimes face a political environment in which traditional nonmarket activities (like lobbying or campaign contributions) do not work well. Bonardi and Keim (2005), for instance, suggest that when activists, NGOs or interest groups succeed at making political issues widely salient - i.e., when a large portion of a population knows and cares about an issue, and thus watches closely as policy-makers make 
decisions - firms cannot react by developing traditional nonmarket strategies (such as campaign financing, lobbying or constituency building), and they face all sorts of problems when they do. By changing the nature of the competitive game, activists or interest groups can create an external limitation to nonmarket strategies.

Insert Figure 1 about here

The third limitation to firms' nonmarket activities is related to the policy-makers themselves. For ideological reasons or because their main goal is to build legitimacy, they might not respond positively to firms' nonmarket activities. This is particularly the case when firms have to deal with regulators, whose position and legitimacy - especially in newly deregulated industries - is, by itself, uncertain (Majone, 1990). In these cases, firms often face a problem because, as profitmaximizers, the information they transmit to policy-makers through lobbying actions is often seen as only moderately credible (Bonardi et al., 2006). In that context, firms cannot effectively develop traditional nonmarket strategies (Lyon and Maxwell, 2004). Similarly, policy-makers might jeopardize their reputation by responding to firms' nonmarket strategies within certain contexts, even if these firms have strong political clout. During the Enron collapse, for instance, Enron executives sought relief from the Bush administration. Even though they were well acquainted with Enron, the Secretaries of Commerce and Treasury decided not to respond. Donald Evans, then Secretary of Commerce, explained: "If I had stepped in, I think it would have been an egregious abuse of the office of Secretary of Commerce.",ii

These last two external limits to firms' nonmarket activities are, in fact, mainly limitations to their effectiveness. However, it is not always clear whether they will lead to fewer nonmarket activities. Rather than generating fewer efforts, increased nonmarket competition, for instance, 
might generate more efforts from all participants, including firms, or even other kinds of nonmarket activities - outside direct lobbying or campaign financing - (Bonardi and Keim, 2005). The same can be said of the second type of limitation, where firms might decide to finance opposed or favorable interest groups instead of acting directly in their own name (Lyon and Maxwell, 2004). The question becomes: Are there any other limitations to firms' nonmarket activities?

The key thesis of this paper is to suggest that, in addition to the external limits suggested by the existing literature, and in spite of the fact that market and nonmarket activities are often presented as perfect complements, there are, in fact, internal limitations to nonmarket activities. By "internal" we mean limitations related to constraints rising from within the firm (rather than from its external environment).

\section{Internal limits to firms' nonmarket activities}

Viewed from the lens of a political market that includes both demanders and suppliers of public policies (Bonardi, Hillman and Keim, 2005), nonmarket activities do not depend solely on clout or on connections with policy-makers. They also depend on what firms can bring to the policy-makers who will be making policy changes. A traditional assumption about policy-makers is that they try to maximize their chances of being re-elected (Stigler, 1971). Within the context of policy change, what can the incumbents bring to the policy-makers in order to achieve this objective? Obviously, there are many plausible answers, and we have already seen that firms can provide important assets such as information or financial resources. However, from this perspective, other types of resources might also be considered. For instance, one of the greatest fears of policy-makers in current democracies is the threat of unemployment (Cawson et al., 1990). Large firms are also large employers, and they might be tempted to lay off a part of their 
workforce in order to improve their competitiveness. This would have a negative impact on unemployment figures and might jeopardize the government's position by harming its economic results or by creating social troubles. Therefore, one powerful way that incumbents can help policy-makers in their quest for re-election is by committing to job preservation within their industry.

From a theoretical point of view, this discussion indicates that nonmarket activities, because they require commitments of economic inputs (such as human resources, in this case), are at least partially dependent on market activities (Bonardi, 2007). A firm's offer to strike a deal with policy-makers has potentially important consequences for the firm's market operations. Still building on the example above, one can easily see a potential conflict between the fact that firms are constantly trying to transform into more competitive players but, at the same time, they may commit to freezing one of the main aspects of these market inputs - in this case, again, human resources. One can go even further and argue that maintaining nonmarket commitments would jeopardize the firm's market activities. Managers, therefore, face a trade-off - i.e., market and nonmarket activities are no longer complements but rather substitutes - and they are likely to choose their core market activities over nonmarket activities. This is the source of the internal limits to nonmarket activities within firms. Figure 1 tries to capture this tension by showing how market and nonmarket activities, in order to be efficient, must depend on the commitment of common economic inputs. The larger the overlap (dependence) between the two types of activities, the more likely it is that managers will face difficulty in integrating them.

When do these trade-offs occur? Building on the idea that market strategies are also strongly supported by commitments (Ghemawat, 1991), one might see that conflicts between market and nonmarket activities building on common inputs will appear when market commitments towards 
certain strategies need to be strengthened. In such a case, most of the available inputs will have to be channeled towards market activities, thereby pushing the firm to give up its nonmarket commitment and, as a result, significantly restricting its nonmarket activities. Irrespective of how deep firms' pockets may be, these internal limits should occur endogenously.

From this discussion, we can derive two key empirical predictions. First, firms' nonmarket activities, through the commitment of some economic inputs, should have a positive impact on the firms' ability to secure favorable regulations, at least in the early stages of new strategies development (when market and nonmarket activities are still complementary). Second, the impact of these nonmarket commitments should decrease as the two types of activities tend to overlap and depend on a common pool of economic inputs.

\section{Empirics}

We explore the theory within the context of European telecommunications deregulation (for the period from 1983 to 2000), which was a period of important policy changes, and we concentrate on the case of the deregulation of former monopolies. This empirical set-up has two interesting characteristics for considering within our theory. First, in this setting, firms' market and nonmarket objectives are relatively clear: as former monopolies with presumably high costs, they face the prospectives of tough competition in their core businesses; nonmarket activities are a way to slow the deregulation process and the entry of competitors, which gives the firms time to become more competitive actors. There is, therefore, what might appear to be natural complementarities between these firms' market and nonmarket strategies. In this empirical section, we will try to observe whether these complementarities tend to decay (the sign that there are internal limits to the integration of market and nonmarket activities) or not. 
The second attractive characteristic of this industry for our empirical exercise comes from the fact that it provides ways to approach some measurement of firms' nonmarket commitments. In debates surrounding telecom deregulation in Europe, there were, in effect, strong discussions around notions of 'public service' (i.e., the idea that telecom services should be made available to the whole population at similar prices) and of unemployment (i.e., the idea that deregulation of a major industry would require lay-offs of many employees to transform monopolies into competitive actors) (Cawson et al., 1990). These debates were consistent across Europe, and it is clear that the managers of former monopolies have been able to build on their outcomes within the context of their nonmarket strategies (Bonardi, 1999; Campbell, 1994). This will allow us to derive comparative measures of how strictly firms adhered to these nonmarket commitments.

Finally, the European telecom sector started to become deregulated in the United Kingdom in 1983, which is why we started our data collection there. It then spread throughout Europe, mainly through the action of the European Commission (Cawson et al., 1990). In the early 1980s, however, telecom monopolies did not have clear competitive strategies per se. The last key advantage of this set-up for our empirical investigation is that we observe the development of competitive market activities within these firms from their origin. Our key argument in this paper concerns the fact that internal limits to nonmarket activities tend to appear in an evolutionary way once firms' market strategies become sharper and require more flexibility, and this empirical set-up will allow us to capture that evolution.

Another advantage of our empirical set-up is that it somewhat limits the role of the external limits to nonmarket activities mentioned above. From a nonmarket standpoint, former monopolies are clearly extremely influential in shaping the new regulatory process and its speed. External limits to this in European countries - both nonmarket competition and regulators' 
behaviors - are not insignificant, but they are still limited. If they exist, limitations to firms' influence on the policy-making process are, therefore, more likely to come from the inside.

In what follows, we describe a procedure in which we estimate the impact of firms' nonmarket activities (commitments) on the degree of regulation of telecom domestic telecom markets. We use the development of new strategic directions on the market side to study whether there are any increasing integration issues that might limit the impact of nonmarket commitments on the degree of market regulation. In this study, the degree of market regulation will be the dependent variable, with the main independent variable being the extent to which firms make nonmarket commitments.

\section{Data}

Our sample consisted of the 14 major telecommunications operators in Europe from 1983 through 2000, i.e, almost the entire population, based on the criteria highlighted above. ${ }^{\text {iii }}$ The first comment that needs to be made is that some of these operators came from countries that were not yet members of the European Union (EU) at the beginning of the sample; some were still not members in 2000 . However, none of these countries, because of their proximity or because they wished to enter the EU, could remain untouched by deregulation (Noam, 1992). Similar institutional and competitive pressures can therefore be observed in countries like Spain, Switzerland or Austria, even though they were not part of the EU in 1983.

Operators of three countries were omitted from the sample: Italy, Luxembourg and Finland. In the case of Luxembourg, not enough information was available. In the case of Finland and Italy, their telecom market structure was too different from that of other European countries when deregulation started - particularly because of their use of separate operators for local, longdistance and international calls, instead of having one single monopoly. Eastern European 
operators were also not included due to obvious technological and institutional differences with Western European countries. We chose to concentrate on European OECD members only.

The sample starts in 1983 for two reasons. First, this is the date when the first European market, the United Kingdom, was opened to competition. Even if all the telecommunications markets in Europe were not deregulated at that time, strategic expectations of operators changed as of this date, with the entire deregulation of the European market growing closer to competition every day (Noam, 1992). Second, 1983 is also the year when the Commission first became officially involved in the telecom sector, with clear objectives towards liberalizing the sector. For these two reasons, even though the first regulatory steps had not been made at that time, the deregulation process and strategic thinking about how to improve the companies' competitiveness began for the major telecom actors at this time.

\section{Dependent Variable}

Market Regulation. For the dependent variable, we evaluate an indicator based on OECD sources (OECD, 1995, 1997, 1999, 2001). The indicator takes into account the evolution of market regulation for two key fixed-line telecommunications markets: the local market and the long distance market. As the long distance market was liberalized first in European countries, we assign a 5 to the Market Regulation indicator when this market is still a monopoly, a 4 when it becomes a duopoly, and a 3 when it becomes competitive (with at least three competitors). When the local telecom market becomes a duopoly, the indicator takes a value of 2 and finally of 1 when this local market is competitive. We chose these markets because they were the key markets in the early 1980s, giving us consistency throughout the sample. Additionally, one must note that the liberalization of these markets took place sequentially, with the long distance 
market being liberalized first, meaning that our measure is an ordered variable. This will have implications on the econometric technique used to analyze the data.

\section{Independent Variables: Nonmarket commitments}

The main independent variables are those that are related to the nonmarket commitment of former monopolies. As explained earlier, at least two dimensions created intense political debates in European countries: (1) the levels of unemployment and the lay-offs that might occur with deregulation, and (2) questions around the universal service, i.e. local and long-distance services guaranteed on all the country's territory and with similar prices everywhere (Cawson et al., 1990; Noam, 1992). Because these issues were closely scrutinized by voters, they represented good opportunities for firms to make a related nonmarket commitment, thereby boosting their own chances to influence the policy-making process. We build on this characteristic in our empirics, and therefore concentrate on two variables to capture firms' nonmarket commitments.

Unemployment nonmarket commitment (UNC). First, we evaluate the number of employees the former monopoly would have to lay off to reach the level of productivity of the most efficient telecom operators in the world, scaled to the operator's number of employees. We make the following computation: $\mathrm{UNC}_{\mathrm{x}}{ }^{\mathrm{t}}=\left(\mathrm{E}_{\mathrm{x}}{ }^{\mathrm{t}}-\left[\left(\mathrm{E}_{\mathrm{D}}{ }^{\mathrm{t}} / \mathrm{L}_{\mathrm{D}}{ }^{\mathrm{t}}\right) * \mathrm{~L}_{\mathrm{x}}{ }^{\mathrm{t}}\right]\right) / \mathrm{E}_{\mathrm{x}}{ }^{\mathrm{t}}$

where $E_{x}{ }^{t}$ is the number of employees of operator $x$ for year $t, L_{x}{ }^{t}$ is the number of main lines of operator $\mathrm{x}$ for year $\mathrm{t}, \mathrm{E}_{\mathrm{D}}{ }^{t}$ is the number of employees of the most efficient operator for year $t, L_{D}{ }^{t}$ is the number of main lines of the most efficient operator for year $\mathrm{t}$ and $U N C_{\mathrm{x}}{ }^{\mathrm{t}}$ is the indicator of the unemployment nonmarket commitment made by the firm to the policy-makers.

Universal Service Nonmarket Commitment (USNC). For universal service considerations, we estimate a simple indicator of the cross-subsidies that each operator maintains over the course of the deregulation process. The defense of this universal service is generally under the authority of 
an industry-specific bureaucracy and constitutes a large part of its legitimacy. Therefore, we argue here that the former monopoly maintains significant influence over regulatory decisions as long as it respects this universal service requirement. Because cross-subsidies are generally considered necessary in order to fulfil these universal service requirements, we try to assess the level of cross-subsidies for each operator. We measure the difference between long distance charges and local charges. A large difference indicates that long distance charges subsidize local charges, which was a common practice among telecom operators when the sector was considered to be a natural monopoly in charge of universal service.

\section{Independent Variables: Operators' market strategy}

For the purposes of testing our theory, it was also important to include data that captured the commitments made by former monopolies regarding their market strategy. This allowed us to explore whether the commitments made for market strategies tended to enter in conflict with nonmarket commitments, thereby making it necessary for firms to limit some of their nonmarket activities to favor the development of their market strategies. We consider the commitments that most former monopolies have engaged in throughout the 1980s and 1990s. These commitments have to do with: (1) improving the quality of service provided to consumers, (2) developing new networks and especially wireless networks, (3) product and service diversification, and (4) international expansion.

Market commitment to service quality improvement: We measure this commitment by the ratio of digital main lines to the total main lines, which estimates the network's technological sophistication. 
Market commitment to new infrastructure development: The penetration rate of cellular phone technology in each country (note that this network development has been supported mainly by former monopolies over our sample);

Market commitment to diversification: The percentage of revenue realized in areas other than vocal telephony, which indicates the company's degree of diversification and thus its potential to discover new opportunities and create new products.

Market commitment to international expansion: The number of countries in which the operator has a subsidiary or an alliance, which suggests the firm's capacity to identify new needs in outlying geographical areas or to propose global services to multinational customers.

\section{Control Variables}

Privatization (PRIV). Most of the operators in our sample were state-owned firms in 1983, but were eventually partially privatized during the deregulation process. This variable indicates which percentage of the firm's capital has been privatized (Range: 0\% when fully state-owned and $100 \%$ when fully privatized).

Other control variables. We added several other variables to control for the size of the operator (Operator revenues ( $R E V)$ collected through the OECD), and the size and output of the operator's country (country GDP per capita $(G D P)$ ), and a dummy variable that indicates whether the country belonged to the European Union (EU) at the beginning of the sample. We also added a variable indicating whether an independent regulatory authority (Indep Reg) has been created (a common practice for deregulation processes, and one that could create external limits to nonmarket activities as explained earlier). Finally, we added a variable based on an 
index of the government's position on the right-left political dimension (this variable takes higher values for right wing parties and is based on a calculation by Budge et al. (2001)).

\section{Methods}

Since our database is a panel and the dependent variable is not purely linear (our Market Regulation variable, as mentioned earlier, is an ordered variable), using a linear regression model would probably lead to biased estimates. In the Market regulation variable, in effect, it is not obvious that the intervals between adjacent categories are really of equal length. For instance, is moving from a 5 to a 4 in terms of the Market regulation measure the same thing as moving from a 3 to a 2 ? The answer is probably that this is not the case. For this reason, we have chosen to use a so-called "ordered probit model" to address the issue of the ordinal nature of the dependent variable. Because of the panel nature of the sample, including firm random effects might also lead to a more accurate estimate. In our ordered probit model with firm random effects, the error term comprises two components: a firm specific term and a noise error term.

$$
\begin{gathered}
\text { Marketregulation }_{i t}^{*}=\alpha+\beta+\lambda_{1} \text { Nonmarket }_{i t}+\lambda_{2} \text { Control }+\phi_{i t}+\varepsilon_{i t} \\
\text { Marketregulation }_{i t}=\left\{\begin{array}{l}
5 \text { if } \tau_{4} \leq \text { Marketregulation }_{i t}^{*}<\tau_{5} \\
4 \text { if } \tau_{3} \leq \text { Marketregulation }_{i t}^{*}<\tau_{4} \\
3 \text { if } \tau_{2} \leq \text { Marketregulation }_{i t}^{*}<\tau_{3} \\
2 \text { if } \tau_{1} \leq \text { Marketregulation }_{i t}^{*}<\tau_{2} \\
1 \text { if } \tau_{0} \leq \text { Marketregulation }_{i t}^{*}<\tau_{1}
\end{array}\right.
\end{gathered}
$$

where Marketregulation $_{i t}^{*}$ is the latent variable, Marketregulation $_{i t}$ is the categorical variable, and $\tau$ 's are the thresholds that determine the length of each category. The subscript $i$ indexes the companies (countries) $(i=1, \ldots, 14)$, and $\mathrm{t}$ indexes the time periods $(t=1$ [year 1983],..., $t=18$ 
[year 2000]). The identification assumption is that $\tau_{1}=1$, and the model is estimated with a constant.

\section{Results}

Table 1 provides descriptive statistics and data sources.

Insert Table 1 about here

The main regression results are presented in Table 2. First, it is worth noting that in all the models (which reflect different specifications), the standard deviation of the random effects (Sigma) is significant, indicating that the econometric approach is appropriate as unobserved heterogeneity among companies (countries) does matter.

In Table 2, we start with a model including only the control variables (Model 1), and then we move into including the more relevant variables, especially measures of nonmarket commitments (Model 2), then interaction terms exploring internal limits to market-nonmarket integration (Models 3 to 5), and finally, a full model (Model 6). Since the ordered regression models considered here are not linear in the outcome probabilities, the interpretation of coefficients, in terms of magnitude, is therefore not straightforward. For this reason, in our discussion, we focus mainly on the sign and significance of coefficients.

Insert Table 2 about here

Looking first at control variables, one should note that EU membership and privatization has a significant and negative impact, which suggests that the higher they are, the more policies tend to move towards liberalization. The creation of an independent regulator has a similar effect. These results are expected. 
We then consider our measures of nonmarket commitments. The two measures of nonmarket commitment (NCU and NCCS) have a significant and positive impact on all models, supporting the proposition that firms do use nonmarket commitments to obtain favorable market regulation (in that case, a slower process towards market liberalization and competition).

Finally, we consider the core of our argument, i.e., the idea that there might be integration issues between market and nonmarket activities. Again, these integration issues should tend to mount the more the firms intensify their efforts to develop their market strategies. In effect, economic inputs used for nonmarket strategies could tend to require different usages and development for the purpose of market strategies. As trade-offs appear, firms will probably tend to favor the most important part of their activities (i.e., their market activities) and will therefore reduce or change the nature of their nonmarket activities.

To test this idea, we introduce into the models our measures of market commitments as interactions with the two measures of nonmarket commitments. We also add each market commitment variable itself, as needs to be done to insure that the interactions really matter in our models. Model 3 provides results regarding firms' market commitment towards quality of service improvement. For both the unemployment commitment variable and the universal service variable, the interaction is negative and significant, suggesting that there are indeed some internal limits in integrating market and nonmarket activities when the commitments related to quality of service improvement strengthen.

On the other hand, in Model 4, only the interaction between firms' unemployment commitment and the development of a wireless network is significant and correctly signed. Model 5 shows the opposite trend: only the interaction between firms' commitment to universal service and diversification is significant, and the sign goes in the opposite direction from the one 
expected. For our sample, integration issues do not seem to matter, and market and nonmarket activities remain complementary. One explanation for this might be that product and service diversification for the period considered might be too limited and erratic to really generate integration issues.

In Model 5, the interaction between firms' commitment to universal service and international expansion is this time negative and significant, suggesting that there might indeed be some problems in integrating defensive nonmarket activities at home and expanding internationally. This result is in line with previous findings by Bonardi (2004). On the other hand, the interaction between firms' commitments to unemployment and firms' international expansion is not significant.

Model 6 is the full model containing all the variables. Most of the important relationships discussed below are relatively stable here.

\section{Discussion and conclusion}

From the above results, we must ask: Should we be pessimistic about policy changes in a democracy because of firms' ability to influence political or regulatory choices? Based on a study of European telecommunications operators facing deregulation, this paper provides mixed responses to that question. On the one hand, we find that firms can indeed influence policy changes through the nonmarket commitments they make. This result is interesting for two reasons. First, because it is in line with the existing nonmarket strategy literature and therefore supports the key proposition of this literature that firms can derive regulatory advantages from their nonmarket activities. It is also compatible with the private interest theory of regulation (Stigler, 1971) and the modern political economy literature in general (Grossman and Helpman, 
1994), according to which public policy decisions in a democracy result for a significant portion from corporate lobbying.

This result departs from these literatures, however, by suggesting that nonmarket commitments are as important (and may be more) than traditional political resources such as campaign contributions, lobbying skills or political connections. Committing economic inputs for political purposes, thus, can be in certain contexts a powerful way to influence public policymaking (Bonardi, 2008). This also suggests that commitments are as important for nonmarket strategies than they are for market ones (Ghemawat, 1991).

However, we also find that there are cases where firms experience problems in integrating their market and nonmarket activities when the market commitments required for firms' market strategies strengthen. This speaks to the idea that market and nonmarket activities are not always complementary; in fact, firms sometimes face trade-offs and have to restrict their nonmarket activities to support the development of their market activities. The main result of this paper is to theoretically explain the nature of these internal limits to firms' nonmarket activities and to show that there might be some empirical support for this idea.

Naturally, one needs to consider our empirical results with caution. First, we somewhat arbitrarily chose our measures of market and nonmarket commitments from among other potential ones, a point that might have driven some of our results. Second, we tested our framework within a very specific context. To prove the generality of the idea of internal limits to firms' nonmarket activities and to support the idea that these internal limits are related to marketnonmarket integration problems, one would have to find similar results in other industries and contexts. We hope that some researchers will engage in this line of research. 
The implications of this study are not limited to prospects for policy changes, but they do speak to more general questions: Do corporations dominate politics in modern democracies (Quinn and Shapiro, 1991)? Is this a key issue for the democratic system itself? Should firms' nonmarket activities be more closely regulated (thereby strengthening one of the external limits stressed in this paper)? Clearly, the present paper will not settle these debates. It does, however, shed some new light on a point that has not been taken into account in the literature (Block, 1977; Epstein, 1969). The results put forward in this paper, in effect, suggest that there is an inherent limit to the ability of firms to use nonmarket activities to control policy processes. As long as these firms seek profits and are involved in a competitive process that requires some strategic focus on market activities, certain nonmarket actions will have to be discarded in order to avoid the integration issues that arise from the commonalities of market and nonmaket inputs. If true, firms' involvement in public policy debate might be less problematic than considered in previous literature (Reich, 1998), and would require less attention than one might expect from consumers, organized interest groups, NGOs or activists. 


\section{REFERENCES}

Amacher, Ryan Higgins, Richard, Shughart, William and Robert Tollison. 1985. "The Behavior of Regulatory Activity over the Business Cycle: An Empirical Test.” Economic Inquiry. 23: 7-19.

Ansolabehere, Stephen, de Figueiredo, John., and Snyder, Jim. 2003. "Why is there so little money in U.S. politics?" Journal of Economic Perspectives, 17: 105-30.

Barney, Jay and Ed Zajac, 1994. "Competitive Organizational Behavior: Towards an Organization-allybased Theory of Competitive Advantages.” Strategic Management Journal. 15: 5-9.

Baron, David, 1999. "Theories of Strategic Nonmarket Participation: Majority-Rule and Executive Decisions." Journal of Economics and Management Strategy. 10, 1: 47-90.

Baron, David, 1995. "Integrated Strategy: Market and Nonmarket Components." California Management Review, 37, 2.

Baron, David, 2006. Business and its Environment. Prentice Hall: Upper Saddle River, New Jersey, Fifth Edition.

Baumgartner, Frank and Bryan Jones. 1993. Agendas and Instability in American Politics. Chicago: University of Chicago Press.

Baumol, William and Janusz Ordover. 1985. "Use of Antitrust to subvert competition." Journal of Law and Economics. 28, May.

Block, Fred. 1977. "The ruling class does not rule.” Socialist Revolution. 33: 6-28.

Bonardi, Jean-Philippe. 2008. "Nonmarket strategies and asset freezing." Working paper, University of Lausanne, Faculty of Business and Economics.

Bonardi, Jean-Philippe. 2004. "Political and international strategies of former telecom monopolies: The Asymmetric Behaviors of Former Monopolies.” Strategic Management Journal. February. 25 (2): 101-120.

Bonardi, Jean-Philippe. 1999. "Market and Nonmarket Strategies during Deregulation: The Case of British Telecom.” Business and Politics. 1, 2 
Bonardi, Jean-Philippe, Hillman, Amy and Gerry Keim. 2005. "The attractiveness of political markets: Implication for firm strategy.” Academy of Management Review. 30 (2): 397-413.

Bonardi, Jean-Philippe, Guy Holburn and Rick Vanden Bergh. 2006. "Nonmarket performance: Evidence from U.S. electric utilities.” Academy of Management Journal. December.

Budge, Ian, Hans-Dieter Klingelman, Andrea Volkens, Judith Bara and Eric Tanderbaum. 2001. Mapping policy preferences - Estimates for parties, electors and governments. Oxford: Oxford University Press.

Campbell, James. 1994. "Couriers and the European Postal Monopolies." In Pedler, R.H., Van Schendelen, M.P.C.M., Lobbying the European Union, Dartmouth Publishing: Brookfield, Vermont: 123-148.

Cawson, Alan, Morgan, Kevin, Webber, Douglass, Holmes, Peter and Stevens. 1990. Hostile Brothers: Competition and Closure in the European Electronics Industry ${ }_{2}$ Clarendon Press, Oxford

Cave, Martin and Williamson, Peter. 1996. "Entry, Competition and Regulation in the UK Telecommunications." Oxford Review of Economic Policy. 12, 4: 100-121.

Dean, Thomas and Richard Brown. 1995. "Pollution Regulation as a Barrier to New Firms Entry: Initial Evidence and Implications for future Research.” Academy of Management Journal, 38, 1: 288303.

de Figueiredo, John and Brian Silverman. 2006. "Academic earmarks and the returns to lobbying." Journal of Law and Economics.

Derthick, Martha and Paul Quirk. 1985. The Politics of Deregulation. The Brookings Institution: Washington DC

Epstein, Edwin. 1969. The corporation in American politics. Englewood Cliffs: Prentice Hall.

Faccio, Mara, 2006. "Politically connected firms.” American Economic Review. 96: 369-386.

Faccio, Mara, 2007. "The characteristics of politically connected firms." Working paper, Vanderbilt University. 
Faccio, Mara, Masulis, R., McConnell, J. 2006. "Political connections and corporate bailouts.” Journal of Finance. 61, 6: 2597-2635.

Fisman, Ray, 2001. "Estimating the value of political connections." American Economics Review. 91, 4: 1095-1102.

Ghemawat, Pankaj. 1991. Commitment: The dynamic of strategy. New York: Free Press.

Grossman, Gene and Elhanan Helpman. 1994. "Protection for Sale." American Economic Review. 84, 4: 833850.

Hillman, Amy. 2005. "Politicians on the board of directors: Do connections affect the bottom-line?" Journal of Management, 31, 3: 464-481.

Hillman, Amy and Mike Hitt. 1999. "Corporate political strategy formation: A model of approach, participation and strategy decisions.” Academy of Management Review. 24: 825-842.

Hillman, Amy and Gerry Keim, 1995. "International Variation in the Business-Government Interface: Institutional and Organizational Considerations.” Academy of Management Review, 20, 1.

Hillman, Amy, Zardkoohi, Asghar and Leonard Bierman, 1999. "Corporate Political Strategies and Firm Performance: Indications of Firm-Specific Benefits from Personal Service in the US Government.” Strategic Management Journal. 20: 767-811.

Holburn, Guy and Rick VanDen Bergh, 2002. "Policy and Process: A Game-Theoretic Framework for the Design of Nonmarket Strategy." Advances in Strategic Management. 19: 33-36.

Keim, Gerry and Barry Baysinger, 1988. "The efficacy of business political activity: Competitive considerations in a principal-agent context." Journal of Management, 14:163-180.

Levy, Brian and Pablo Spiller, 1994. "The Institutional Foundations of Regulatory Commitments: A Comparative Analysis of Telecommunications Regulation.” Journal of Law, Economics and Organization. 10, 2: 201-246.

Lyon, Tom and John Maxwell, 2004. Astroturf: Interest group lobbying and corporate strategy. Journal of Economics and Management Strategy. 13, 4: 561-597.

Majone, Giandomenico. 1990. Deregulation or Re-regulation? Saint Martin's Press, New York. 
McCormick, Robert, Shughart, William and Robert Tollison. 1984. "The disinterest in deregulation." American Economic Review. 74: 1075-1079.

Noam, Eli. 1992. Telecommunications in Europe, New York: Oxford University Press.

OECD, 1995 1997, 1999. Perspectives of Telecommunications, OECD: Paris.

OECD, 1995. Telecommunication infrastructures: The advantage of competition. OECD: Paris.

Quinn, Dennis and Robert Shapiro. 1991. "Business political power: The case of taxation." American Political Science Review. 85: 856-871.

Reich, Robert. 1998. "The meaning of corporate social responsibility”. California Management Review. 40, 2: 8-17.

Schuler, Doug. 1996. "Corporate Political Strategy and Foreign Competition: the Case of the Steel Industry". Academy of Management Journal. 39, 3: 720-737.

Shaffer, Brian., Quasney, Thomas and Curtis Grimm. 2000. "Firm-level performance implications of nonmarket actions.” Business and Society, 39: 126-143.

Spiller, Pablo and Carlo Cardilli. 1997. "The Frontier of Telecommunications Deregulation: Small Countries Leading the Pack.” Journal of Economic Perspectives. 11, 4: 127-138.

Stigler, George. 1971. "The Theory of Economic Regulation." Bell Journal of Economics and Management Science, 6, 2: 3-21.

Thatcher, Mark. 1999. The Politics of Telecommunications. Oxford University Press: New York.

Teske, Paul. 1991. "Rent-Seeking in the Deregulatory Environment: State Telecommunications." Public Choice. 68, 1: 235-243.

Troesken, Werner. 2007. "Competition and corruption: Lessons from 150 years of industrial governance.” Working paper, Mercatus Center, George Mason University.

Tullock, Gordon, 1975. “The transitional gains trap.” Bell Journal of Economics. 6, 2: 671-678.

Tullock, Gordon, 1967. "The welfare costs of tariffs, monopoly and theft." Western Economic Journal. June: $224-232$. 
Vietor, Richard. 1994. Contrived Competition: Regulation and Deregulation in America. The Belknap Press of Harvard University Press.

Wenders, J. 1987. The Economics of Telecommunications: Theory and Policy. Cambridge: Ballinger.

Winston, Clifford, 1998. "U.S. Industry Adjustment to Economic Deregulation." Journal of Economic Perspectives, 12, 2: 175-196.

Yoffie, David, 1988. "How an Industry builds Political Advantage." Harvard Business Review. May: 8289.

Zardkoohi, Asghar. 1985. "On the political participation of the firm in the electoral process." Southern Economic Journal, 51: 804-817. 
Figure 1 Limits to firms' nonmarket activities

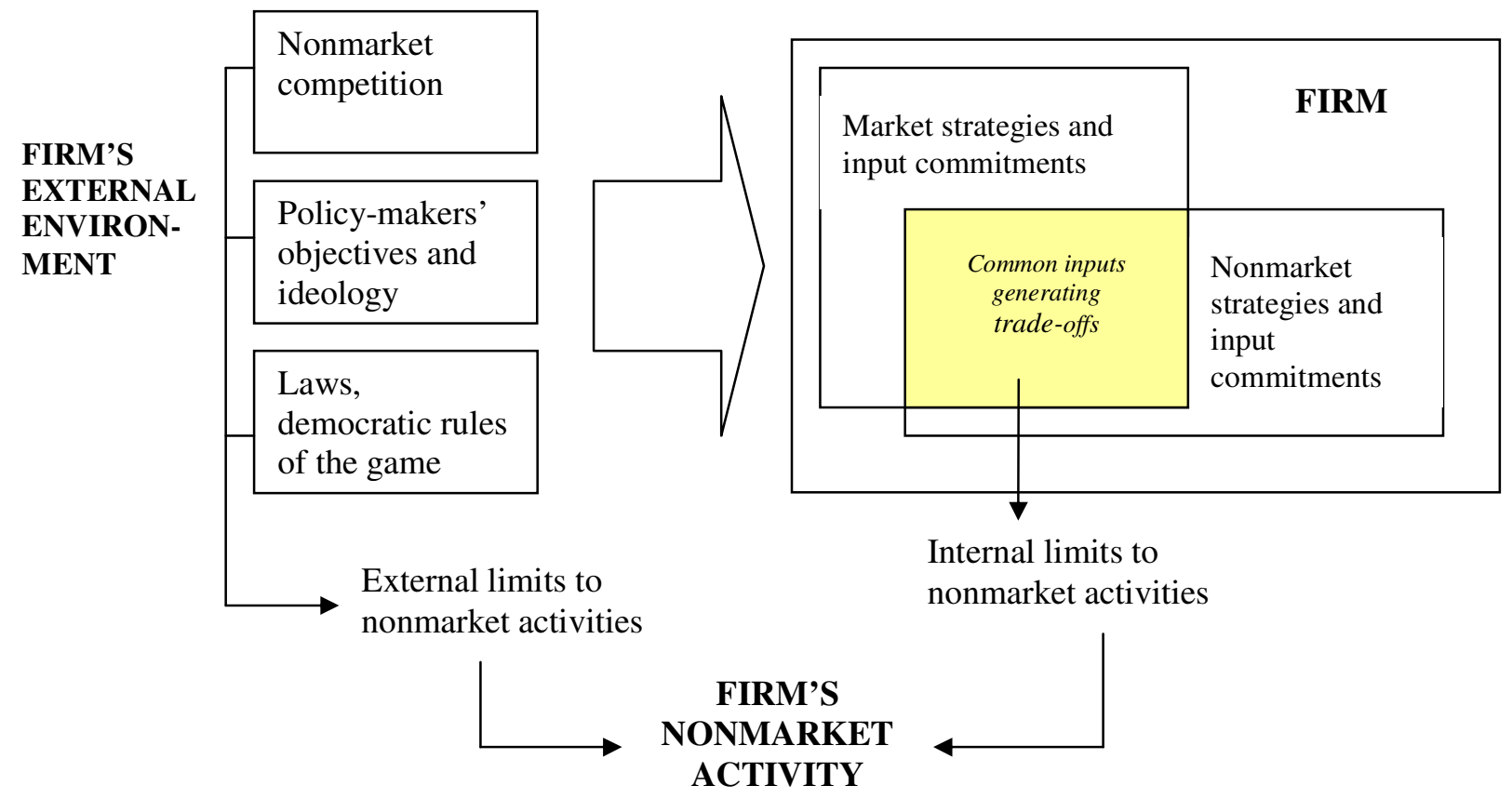


Table 1 Descriptive statistics

\begin{tabular}{lccc}
\hline \multicolumn{1}{c}{ Variables } & Mean & Standard deviation & Source \\
\hline Marketregulation (MR) & 3.95 & 0.92 & OECD \\
& & & \\
Unemployment Nonmarket Commitment & .18 & 0.31 & OECD, ITU \\
(UNC) & 1.53 & 0.85 & OECD, ITU \\
Universal Service Nonmarket & & & \\
Commitment (USNC) & & & \\
& 25.70 & 18.24 & OECD \\
Service quality & 0.03 & 0.05 & OECD \\
New network & 0.20 & 0.11 & Company reports, \\
Sector diversification & & & OECD \\
& 1.37 & 2.84 & Company reports \\
International expansion & & & \\
& 339 & 131 & OECD \\
Revenues & 15.8 & 3.4 & OECD \\
GDP & .48 & .42 & OECD \\
Privatization & 1.05 & 18.5 & Budge et al. (2001) \\
Ideology (Right-Left) & .58 & .45 & OECD \\
Independent regulator & 0.34 & 0.51 & EU website \\
EU membership & & & \\
\hline
\end{tabular}


Table 2 Panel Regressions - Ordered probit with random effects

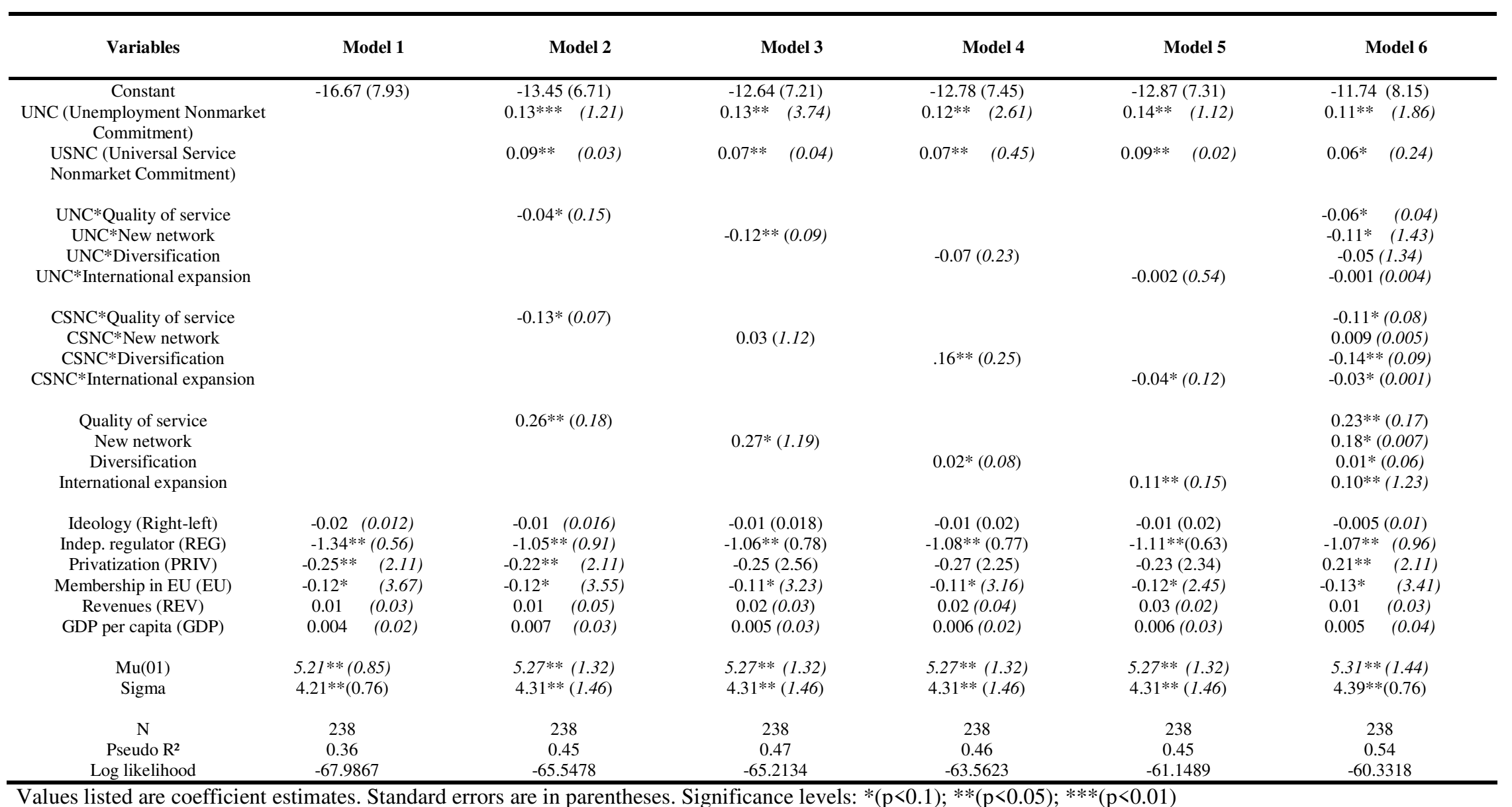

Values listed are coefficient estimates. Standard errors are in parentheses. Significance levels: $*(\mathrm{p}<0.1) ; * *(\mathrm{p}<0.05) ; * * *(\mathrm{p}<0.01)$

Panel regression analysis using ordered probit models with the degree of market regulation as dependent variable and measures of nonmarket commitments as

main independent variables. Other specifications include interactions of market and nonmarket strategic commitments. 
${ }^{i}$ See "Climate change hot topic for lobby industry," Canada.com network, www.canada.com, January 21, 2008.

${ }^{\text {ii }}$ See Baron (2006), 687.

iii These operators were former monopolies in the following countries: Austria, Belgium, U.K., Germany, France, Ireland,

Netherlands, Nortel, Portugal, Greece, Switzerland, Denmark, Spain and Sweden. The names of the companies noted here are the most recent ones. In effect, many operators changed names during the deregulation process. 